\title{
LIMINALITY: BLACK DEATH 700 YEARS LATER. WHAT LESSONS ARE FOR US FROM THE MEDIEVAL PANDEMIC?
}

\author{
WOJCIECH BEDYŃSKI ${ }^{1}$ \\ ${ }^{1}$ University of Warsaw, Centre of Migration Research, Pasteura 7, 02-093 Warszawa. Poland. ORCID: \\ 0000-0002-4752-5117, Email:w.bedynski@uw.edu.pl
}

\begin{abstract}
Black Death, global plague of the $14^{\text {th }}$ century deeply changed the society of Medieval Europe. This unexpected catastrophe killed from 30 to 60 per cent of the continent's population remaining the most deadly of all known wars, epidemics or natural disasters up to date ${ }^{1}$. It was an impulse to a profound transformation of European society, religiosity and art that opened doors for the Renaissance. Time of the catastrophe had a clearly liminal character, well described in Boccaccio's Decameron. It is far too early to predict the COVID-19 pandemic's impact on the world in longtime perspective, as we know little about how and when the disaster will end, but mechanisms of the liminal period are already to be seen and can be described, so is the influence of the virus on global economy, mobility, culture. There are similarities even in human reactions - from the hostility towards Asians (pogroms of Jews as a reaction to the Black Death) to 'corona-parties' (similar to the plays described by Boccaccio). KEYWORDS: pandemic, Black Death, mobility, social structure, religiosity, liminality
\end{abstract}

\footnotetext{
${ }^{1}$ In percentages, not real numbers. $2^{\text {nd }}$ World War took more lives, but Europe's population was much bigger then. We must be aware however, that even greater percentages of people died of contagious diseases that appeared in both Americas when European colonists transported unknown pathogens to new populations (like the plague of smallpox from 1520 in Mexico).
} 
...There came the death-dealing pestilence, which, through the operation of the heavenly bodies or of our own iniquitous dealings, being sent down upon mankind for our correction by the just wrath of God, had some years before appeared in the parts of the East and after having bereft these latter of an innumerable number of inhabitants, extending without cease from one place to another, had now unhappily spread towards the West. And thereagainst no wisdom availing nor human foresight (whereby the city was purged of many impurities by officers deputed to that end and it was forbidden unto any sick person to enter therein and many were the counsels given for the preservation of health) nor yet humble supplications, not once but many times both in ordered processions and on other wise made unto God by devout persons, about the coming in of the Spring of the aforesaid year, it began on horrible and miraculous wise to show forth its dolorous effects.

Giovanni Boccaccio, Decameron

\section{INTRODUCTION}

Current coronavirus pandemic outbreak may seem to the public opinion exceptional and coming out of a sudden. It might be so because there is no more communicative memory (Assman 2008) of the Spanish Flu of 1918-2020, that took an estimate number of 24.7 to 39.3 million lives worldwide and over half a billion cases of infection (Patterson and Pyle 1991: 15). In fact regional and continental plagues repeated regularly in the human history. Of them first mentioned was the great plague of Athens in 429 BC. Thucydides wrote (1988), that it started in Ethiopia and reached Athens through Egypt. No cure was known to medics and what helped ones, worsened situation of others. Greek historian ads, that the plague came from Ethiopia, which suggests that he was aware of its natural not supernatural provenance, but at the same time he recalls a hypothesis, that it was caused by the poisoning of wells by Spartans, who were in war with Athenians at that time (Naphy and Spicer 2004:7).

Later came the plague of Antonine (165-180 AD), plague of Justinian (541-542 AD), the Great Plague of London (1665-1666 AD) and many other deadly catastrophes to which mankind had no cure nor explanation. But none of the historical epidemics nor pandemics has caused such a long term cultural and social transformation as the Black Death in 1347-13502. Being conscious of very changed conditions, it seems possible, that the current COVID-19 pandemic has a potential for a similar impact, not even becoming equally deadly.

It is difficult not to point out certain similarities between the Black Death of the $14^{\text {th }}$ century and the COVID-19 pandemic of 2019-2020. In both cases it originated in China and through Italy was brought to Europe. Both diseases were unexpected and both changed completely the way of living, human behaviors and attitudes. It can be interesting to compare the two cases with all respect to changed civilizational condi-

\footnotetext{
${ }^{2}$ The Plague originated in Central Asia before 1346 and ended globally after 1353, but years 1347-1350 are often given as the outbreak of the pandemic for Western Europe.
} 
tions and scientific knowledge.

The spreading of disease shows how the world changed in its mobility over centuries. The Black Death started in late 1330-ies somewhere in central Asia or China. It was preceded by a period of famine. In 2017 a group of archeologists working on three Nestorian cemeteries near the lake Issyk-Kul in Kyrgyzstan confirmed that the reason for some people's death in 1338 and 1339 could be the Plague (Slavin 2019) with suggestion, that it was the same disease that later spread to Europe. All this area was then dominated by the Mongols, who although already divided to several khanates, enabled faster distribution of goods and people throughout the area with renewal of the ancient Silk Road. The disease appeared in Europe through Italian-kept Crimean city of Caffa. When the Mongols besieged the city they were outnumbered by the plague. Before giving up the siege, they decided to catapult dead corpses of their own warriors who died of the illness (Barras and Greub 2014: 498). As an aftermath of this Mongol-Genoese war for Caffa, Black Death was taken to Europe on board of Italian ships crossing the sea to Messina and then some other ports on the Mediterranean. The year was 1347. The disease then spread across the continent, reaching Genoa and Venice in early 1338, papal see in Avignon in summer same year, England and Scandinavia in 1339 and finally Russian states in 1351 (Gottfried 1983: 76).

It is quite easy to calculate, that in the $14^{\text {th }}$ century the Plague needed 4 years to reach all corners of Europe and more than a decade to cross the Silk Road, ravage Europe and appear in the East of the continent. To compare, the Spanish Flu second outbreak in 1918 needed time from early August 1918 to late January 1919 to reach almost every inhabited place on Earth, sparing only few remote islands in the Pacific (Patterson and Pyle 1991: 11). Novel coronavirus in 2020 did the same in less than 3 months.

Therefore what is a finding about both pandemics, the historical and the one happening in front of our eyes? We are connected, but some of us are connected more. Observing the map of the destinations that the virus reached in the first place and those to which it arrived later, it is clear, that the pandemic hit earlier in the rich, developed countries of the northern and western hemispheres (Western Europe, the US) and later arrived to less globalized areas like central Asia, South America or Africa. These regions, as on 26 March 2020, have still much less reported infection cases and causalities. When analyzing Poland alone, most cases happened to develop in big cities or more central regions. Less developed and sparsely populated Podlasie voivodeship for a number of days was free of infection and later remained the least affected part of the country.

People in the Middle Ages attributed the disease to God's will and explained it as "contaminated air"3 (Głowiński and Kościk 2013). They searched for answers about

\footnotetext{
${ }^{3}$ The vision of contaminated air remain very strong in popular imagination. In the Polish religious hymn from $18^{\text {th }}$ century, „Święty Boże, święty mocny...” (supplication - from Latin supplicatio: request, supplication - has a very long tradition in Christianity, reaching at least as far as $4^{\text {th }}$ Century AD. See: Mika 2008: 151) we read a sentence "od powietrza, głodu, ognia i wojny... wybaw nas Panie” (from air, hunger, fire and war... save us Lord"). Air, that is contagious plague, was mentioned in the first place.
} 
the origin ${ }^{4}$ and future of the Plague in the Holy Bible, where they found that the most probable reason of their tragedy was God's wrath for their sins. They also observed the epidemic as an announcement of the Apocalypse ${ }^{5}$. Hence, the adequate reply to the disaster were fast, penance and prayer. Today, in 2020, scientists quickly provided rational theories about the origin of the virus ${ }^{6}$, but still there is a great number of conspiracy theories - from the one describing the pandemic as an effect of intentional or accidental releasing of the virus from a Chinese (or American) laboratory ${ }^{7}$, to perceiving the disease as the beginning of the Doomsday ${ }^{8}$. We see that sometimes the way of thinking of men is not that far from the $14^{\text {th }}$ century as we would like to think.

This article's objective is to highlight several similarities between the Black Death of the $14^{\text {th }}$ century and the COVID-19 pandemic of 2019-2020. Despite a huge technological, mental and socio-cultural gap between the medieval world and the postindustrial globalized society, some common issues can be pointed out. Current situation is unprecedented, as is underlined by many commentators now. But, in fact, it is not the first pandemic to which humanity is confronted. Lesson, although so distant in time, should be revised once again.

\section{LIMINAL TIME}

Needless to say that the pandemic is a time when everything stops. One may just look now (March, 29 ${ }^{\text {th }}$ 2020) out the window and observe empty streets of big European, Asian or American cities or compare flight boards at airports of any day before the coronavirus outbreak and after the spread of the infection. Many people were forced to stop working, which caused a threat of a massive unemployment. Public communication was limited, shops were closed, so were all cultural institutions. Meanwhile many people spend time with their families in isolation, walking or watching TV. From a distance the world looks like it would have been a Sunday or some global holiday.

Many influential figures and authorities forecast, that the world after the coronavirus will not be the same as we knew it from the times before the pandemic (Žižek 2020). Numerous works, comments, talks and reports are now issued and will be written to explain the nature of that change. This new opening combined with ending of what once was and yet with the existing it this "time in-between" of the pandemic, may suggest that we could perceive it as a sort of a liminal time, like it was described by the famous work of Arnold van Gennep (2004). Social and political hierarchies are doubted, future of all aspects of cultural, social, economic life is not taken as granted.

And here again we may draw some analogy to the medieval times. Black Death

\footnotetext{
${ }^{4}$ See Exodus, 12, 29-33.

${ }^{5}$ In the Book of Revelation of St. John we read: "The first angel went and poured out his bowl on the land, and ugly, festering sores broke out on the people who had the mark of the beast and worshiped its image" (Rev. 16,2). The contagious disease was to be first of all seven plagues to come on Earth, so it could appear as an introduction to the Judgment Day (see also Mt 24: 36-44).

${ }^{6}$ Most trusted is the one that the virus originated in bats (Zhou et al. 2020: 270-270).

${ }^{7}$ http://www.asianews.it/news-en/The-hypothesis-of-coronavirus-originating-from-a-laboratory-in-Wuhan-is-plausible-49550.html.

${ }^{8}$ https://edition.cnn.com/2020/03/22/world/doomsday-prophets-coronavirus-blake/index.html.
} 
deeply affected social behaviors, especially in the large (for their time) Italian cities. It is worth to describe a whole spectrum of possible human responses to this extraordinary situation. Giovanni Boccaccio left a great account of them in the prologue to his Decameron (1929). The description is about Florence, that in the years before the Black Death lost about 60\% of its population (Cesana et al. 2017: 17). Some of the people thought that restraint and moderation should be proper reaction to the pestilence. They closed the doors, ate light meals and didn't drink wine, listened to music and tried to forget about the disease ravaging their city. Some others, on the contrary, satisfied all their desires, drank in taverns, sang and feasted. ${ }^{9}$ Some others finally, who were rich, decided to flee the city seeking secure shelter in their countryside manors or residences.

Boccaccio later writes, that in all these groups new habits and new behaviors quickly occurred, that were very different from the ones that they had before. These were visible in funeral rites, marriages and all social events. People forgot their ordinary duties, both in cities and in the countryside, they refused orders from their superiors, only awaited death in their houses. Authority of both terrestrial and divine provenance was neglected, the Church showed up to be equally powerless against the plague as were kings and nobles. New forms of religiosity, as the flagellants, started to appear in this liminal period, that were not subject to any religious structure nor hierarchy of the feudal society.

This decomposition of the up-to-date social, religious and cultural orders, was temporal, but many factors that emerged during the pandemic, allowed or accelerated the transformation leading to the Italian Quattrocento and to the humanism of the Renaissance. In the public debate in 2020 much is being told, that the liminal time of COVID-19 will accelerate social, economic and technological transformations.

Novel virus will impose this liminal period globally for some time, maybe for months. Some changes will be permanent, the memory of that event will certainly stay for long and affect many aspects. It is already reorienting people's attitudes towards government, international agreements, importance of public health care systems, outdoor activities, social life, death, religion, technology. Certainly soon entire books will appear on it. It is impossible to describe all in one short paper, but I will try to touch at least few examples and show them by comparison with how these issues worked in the $14^{\text {th }}$ century.

\section{PANDEMIC AND THE POLITICS}

COVID-19 pandemic reinforced or weakened some centers of power. National state governments become more dominant and the distance between the politics and ordinary people seems to shorten. It is by the fact, that every decision that is communicated in the media (lockdowns, quarantine, closing of shopping centers, travel limitations etc.) is immediately implemented with a direct and personal impact on all our lives. Crisis is not administrated by laws that are processed for months, but by quick

\footnotetext{
${ }^{9}$ Today we also hear of "coronaparties" organized by youth that cannot adjust to strict quarantine rules: https://www.fox29.com/news/police-break-up-corona-party-at-apartment-in-trenton
} 
actions undertaken by central state powers. In the moment of a disaster, when single people seek help in their suddenly worsened situation, state interventionism is what is expected in the first place. It seems also, that when the crisis comes, large international bodies, like the European Union, are temporarily forgotten.

What happened to the solidarity within the European Union when the coronavirus pandemic hit the continent? Many commentators agreed that European solidarity was weak and all countries put their own interest and safety in the first place. Gianluca Di Feo, vice-head of the influential Italian journal La Republicca, writes in Le Figaro on $15^{\text {th }}$ March $2020^{10}$, that the first thing Italy expected from their European partners was masks, goggles, antiseptics and gloves. European partners refused, France and Germany even forbade to export these articles out of their frontiers. The EU was slow in reactions and always adapted to the decisions taken by particular state authorities. Ironically Italy received an aid from two countries that are not in the European Union and usually are not associated with the liberal democracy: that is China and Russia. ${ }^{11}$

COVID-19 pandemic showed how fragile is globalization and how weak are four pillars or "freedoms" of the European Union: mobility of goods, services, capital and labor. Within days the pandemic froze all of them. The virus inscribed in long chain of events revealing a new trend in world's politics: the de-globalization. Brexit, for long postponed and discussed, happened to fall just weeks before the pandemic; war in Syria and the immigration crisis pushed many governments towards protectionism and lowered the rank of international treaties. It is also the trend we observed in politics of Central-European states, especially Hungary and Poland in recent years. Meanwhile pandemic arises a feeling of national solidarity, union in common fight against the virus. It is much more underlined than the need for international cooperation.

Liminal periods have this feature, that they suspend the applicability of widely respected rules. With the passage of time a reflection may come, that some of these rules were simply not needed or imperfect. What can the coronavirus change in our modern political life? After the pandemic's end questions may appear on the efficiency of the authorities in confrontation with the disease. Similar questions arose in the Middle Ages weakening the position of the universal authorities, like the Church or feudal system.

Centers of power, like the Catholic Church showed to be as powerless confronting the plague as all other institutions. The pandemic challenged the Church and questioned its authority on terrestrial issues. Also showed, that priests and monks are same humans as everybody else, they died in same way and in same numbers. This decrease

\footnotetext{
${ }^{10} \mathrm{https}$ ://www.lefigaro.fr/vox/monde/coronavirus-francais-ouvrez-les-yeux-sur-le-drame-que-vit-litalie-livree-a-elle-meme-20200315.

${ }^{11}$ Between 22 and 25 March 2020 Russian Federation sent to Rome 14 military planes with medical supplies with some 100 medical staff (https://www.euractiv.pl/section/polityka-zagraniczna-ue/news/ koronawirus-rosja-wyslala-do-wloch-pomoc-medyczna/). On the boxes there were inscriptions "from Russia with love", which was a reference to the title of one of the movies about James Bond. Earlier, on 12 March 2020 Chinese medical team with 30 tons of supplies landed in Rome (https://www.reuters.com/ article/us-health-coronavirus-italy-respirators/china-sends-medical-supplies-experts-to-help-italy-battle-coronavirus-idUSKBN2101IM).
} 
in human resources among the clergy caused further institutional decline, because the Church needed to replace them quickly - education and spiritual predispositions of the new priests became less important.

Church had already been weakened before the pandemic (Gottfried 1983: 83-84). The papacy was on exile in Avignon. Internal tensions and the lifestyle of high ranked clergy caused that there was a growing gap between the institution and the laity. Black Death only exposed these vulnerabilities. Movement of flagellants that arose during the pandemic was condemned by the Church officials, but despite this fact supported by many people. Privatization of faith was observed also by the growing number of private chapels built in castles and rich manors (Putnam 1915: 14). Many spontaneous and often dangerous actions were undertaken by the people without permission of the Church or state authorities - of them most terrifying was probably the fate of European Jews. During the pandemic they were being accused of poisoning wells, spreading the disease or simply provoking God's vengeance for their distrust in Christ as Savior. Many thousand Jews were burnt on stages in the Western Europe. On $14^{\text {th }}$ February 1349 two thousand Jews were killed in Strasbourg, which the plague has not even reached to that date (Gottfried 1983: 74).

Yet again, local centers of power functioned much better than universal ones. Italian cities remained unharmed in their structural organization - city council in Florence operated and acted even in the worst time of the pandemic. City officials and council workers even received higher wages (Caferro 161). Italian city-states, as the European kingdoms, survived the catastrophe in a much better condition than the Church.

\section{PANDEMIC AND RELIGION}

Privatization of religion came along with general growth of individualism (or individual thinking). New answers started to be searched beyond religion, in science. It was quickly discovered that the disease is spreading through air so the presupposition was made that bad smell was linked to the infection. Hence, the strange costume of Black Death doctors, where bird's like beak was filled with herbs and smelly oils to protect the person from feeling plague's odor. The nature of the disease provoked scientific, not only religious questions. Doctor Guy de Chauliac, medic at papal throne of Clement VI in Avignon started to examine the disease and himself became one of the very few that survived it. He was the author of Inventarium sive Chirurgia Magna, one of the first manuals to practical medicine. He is sometimes called "father of surgery" (Thevenet 1993: 208).

Decomposition of the Church structure, privatization of liturgy, flagellant movements being a non-orthodox popular semi-heretical movement that was successfully challenging spiritual leadership of the institutional power of the bishops - all that led to unprecedented weakening of official liturgy and clergy. Twenty years after the Black Death the biggest crisis in the history of papacy emerged, when Western Christianity was ruled by two popes at once (temporarily even more) - the epoch (1378-1415) that is known as Great Western Schism. The flagellants, followed by the crisis of Papacy, then works of Jan Hus, Council of Constance, period of Hussite wars in Bohemia and 
Silesia - these were steps leading towards the beginning of Reformation.

In the fourteenth century, the pandemic undermined social religiosity paving the way for humanism and individualism of the Renaissance. Will it be the opposite in the 21st century? Contemporary culture is already very individualistic and secular, especially in the West.

In March 2020 the world saw unprecedented views of holy sites of all big monotheistic religions. Empty square of St. Peter in Rome and the pope alone giving the traditional "urbi et orbi" blessing; the area around famous Kaaba in Great Mosque of Mecca remains quiet. Some Jewish families will meet for Pesach only via Skype. The Catholic Church advised to avoid many celebrations of the Holy Week. All central celebrations in Rome, including the Way of the Cross in the Coliseum will have no public. This happens for the first time in recorded history.

While the Black Death caused a diversion from the Church, COVID-19 may cause, in my opinion, a turn towards religiousness or spirituality. It is doubtful however, if this turn will be targeted at the Church. The whole global consumption slowed down, so did the rat race in corporations, party life, socializing. People have more time for reflection on "big topics", like the sense of life. New religious or spiritual movements may occur, but the need for engagement in a certain form of practice will arise. The faith in human omnipotence can be questioned again.

\section{PANDEMIC AND SOCIETY}

In the times when death became so ordinary, people observed that it is also democratic - it came for both rich and poor, noblemen and peasants, bishops and parish priests, knights and merchants. European motif of the Danse Macabre emerged in late $14^{\text {th }}$ and early $15^{\text {th }}$ century from the memory that the generation of survivors had from the times of the pandemic. Johann Huizinga writes (1974: 168), that $15^{\text {th }}$ century instilled in people the idea of transience like no other epoch in the history of human culture. Uncertainty of death and life was also connected with the uncertainty of economic prosperity and future.

We have for long forgotten this experience. Most recent great contact that the Western civilization had with death was the $2^{\text {nd }}$ World War and the Holocaust. Later, in the 50-ties and 60-ties, culture seemed to abandon the topic of death (Ariès 1989). This is why images from Italy with coffins laid in line in the church or taken by military truck to funerals seem shocking to all post-war generations. After a quick and relatively swift end of communism and collapse of the Soviet Union, Europe and most of the Western World entered the best period in its history - last thirty years were the time of integration, friendship, no wars, fairly stable economic growth, prolonged expected duration of life, less stress of catching a disease, almost unlimited mobility ${ }^{12}$. Many signals suggest, that this golden age is now over. Some of issues, like the climate change, were present before, but people were unaware of them, and therefore did not consider to change their happy lives for that reason. Coronavirus is yet another threat that seemingly is about to put an end to this prosperity. The world has entered a more

\footnotetext{
${ }^{12}$ https://www.businessinsider.com/whats-the-best-time-in-history-to-be-born-2014-9?IR=T
} 
difficult period of greater stress, possible long term economic slow-down, social problems. This will very likely also to influence culture, including art, literature, music.

Natural or social catastrophes, like pandemic, wars, economic crises result in breaking of the stabilized reality. This reversal of up to date social structure and universal stress caused by the fear of death, illness or simply atmosphere of threat imposed by the media, lead to creation of a new feeling of community. The spontaneous sentiment of solidarity is not structured, formed by social norms, nor institutional. Individuals are not subject to social roles they had before entering in liminal period. This communitas, as named by Turner (1967) create a new solidarity of units that suddenly became equal in confrontation of the threat. These solidarities are visible in self-help groups, virtual concerts, internet communities.

In the 14th century major European cities experienced a massive depopulation after a period of constant and rapid growth during $13^{\text {th }}$ and early $14^{\text {th }}$ century. Most of them lost over $50 \%$ of the initial number of inhabitants - for example Norwich in England that had a population of 27 thousand in 1333 was reduced to only 7,7 thousand in 1377 (Britnel 1994: 200). Some of the urban centers recovered only after many decades. This decline in the number of inhabitants improved the life standards of those who survived. Not only in towns, but also in the villages. Sudden shortage of manpower forced the landowners to make efforts to keep the peasants on-site. Otherwise they would decide to migrate seeking better conditions. This led to higher incomes and better work conditions. People received more land for their own. That was a first step leading to an end of feudal system and the birth of modern capitalism. Those who didn't want to remain in the village, went to the city, where there also has been a shortage of workers in almost all professions.

One of the impacts of the COVID-19 pandemic could be that the process of urbanization would stop or change. People being quarantined in small flats they bought for unreasonable high prices, discovered, that life in the province would be much easier in these days and the advantage of having a garden is priceless. Pandemic already has confirmed the possibility of having a fully remote internet work in certain professions, thus it may happen that more and more people will choose to escape the urban areas or to live in-between their cottage houses and the office located in city skyscrapers. On the one hand, pandemic can mean a return to localities, to local economic and social systems and networks; on the other hand, the internet can create a stronger network of supra-local connections.

To the people of $21^{\text {st }}$ century limits imposed on their mobility seem irrational and temporal. Mobility was also a symbol of unlimited possibilities and one of crucial factors in the process of globalization - one could always change his or her situation by moving away. There has always been a "plan B”. Social mobility, a possibility to positively change one's social or economic status was linked to spatial mobility and encouraged migrations (see: the concept of motility, Kaufmann et al. 2004). Today lockdowns exist in almost all countries. Each country made own decisions on limitations in the flow of people so again, like in the past, traveler's first check is to review all existing laws and rules. Limitations on mobility are not likely to end very quickly. 
Tourism, which now is estimated to be as much as 10,4\% of the world's GDP - according to the report of World Travel\&Tourism Council (2019) ${ }^{13}$ - will probably not recover for years. It is possible that many hotels, travel agencies, airlines will be bankrupting also long after the end of the pandemic. People will travel less and on shorter distances. Tourism, when reborn, could be therefore more local than global. The pandemic which was a cause for an increased mobility in the $14^{\text {th }}$ century seems to be freezing the mobility in $21^{\text {st }}$ century.

What is definitely changing already and probably will partly continue no matter how long the crisis lasts, is moving the culture and social life online. Not only culture, but also everyday duties and work. Instead of getting things done in person, people will get them done online first and meet only if it is really needed. That would reduce spatial mobility even more. The shift of our social lives online, already visible at least since 2012/2013 and the introduction of smartphones (see Twenge 2019), will probably accelerate after the pandemic. For only couple of weeks of the lockdown, we have observed schools, public institutions, healthcare consulting, shopping, cultural events, even parties - all organized in form of video-conferences, virtual meetings, emails or use of social networks. It is quite possible that new methods of political engagement will go online, including a possibility of on-line voting.

In the $14^{\text {th }}$ century the pandemic also resulted in an explosion of individualism, but also particularism which we observed during the Renaissance. Decomposition of universal Latin and religious culture of the high Middle Ages caused by the Black Death led to emerging of literature in national languages and higher consciousness of identity. How it would affect the postmodern society, well individualistic already? Can it lead to reversion of it and creation of a more collective cultural pattern, even online? Despite the fact that international treaties may seem less important in the times of crisis, human solidarity experiences a revival - especially in local or national context.

It seems that the pandemic would be yet another contribution to the debate on social classes. During the Black Death, lower class was much more affected by the pestilence than the nobles. We read about it in Decameron, where 10 rich citizens of Florence decided to move away from the city. It was possible by many factors - from better hygiene standards to the ability of fleeing to distant countryside manors. Famous was the example of pope Clement VI who in order to save his life, spent weeks in Avignon sitting between two constantly burning fires (Kelly 1997: 307).

COVID-19 opened a great dilemma - what to safe first: lives or economy. If we stop the economy and keep people closed in homes for a long period of time, the stocks will fall, currencies will collapse and the world will face a vast economic crisis. If we don't do it, more people die. If we keep people closed but don't manage to defeat the virus quickly enough, people die anyway as economic crisis would be followed by hunger and more disease, especially in less developed parts of the globe. From the beginning of the pandemic outbreak we observed two different strategies: one, expressed initially by the British government, partly present in Sweden and in declarations of the US president, Donald Trump. Second strategy, adopted by the majority of countries, is to

${ }^{13}$ https://www.wttc.org/-/media/files/reports/economic-impact-research/regions-2019/world2019.pdf 
lock as many things as it is possible.

The first option tells, that the disaster will end when a certain percentage of people will get through it and the "herd immunity" is developed in the society. The supporters of the lockdown strategy are however saying, that the emergence of this "herd immunity" will have to be paid with deaths of hundreds of thousands weaker members of the society: elderly, sick, poor and those living in less developed regions of the world with no access to proper medical care. People with greater chances to survive are the ones that are young, healthy, rich and live in countries where the health care services are at better level. Most privileged of all are corporation workers who can take all work duties to their houses and do it entirely on-line. Less privileged are physical workers, cleaning staff, sales, delivery or care workers. Again, modern world does not differ much from medieval realities.

During the Black Death people blamed others for the pestilence, especially those who were often blamed, that is Jews, Gypsies, lepers, all travelers and strangers (Shipman 2014: 410). It is too early to predict how the COVID-19 pandemic will impact the attitude towards strangers or immigrants in long-term perspective, but we may assume that it will reinforce anti-immigrant feelings, as the fear of being infected will correlate with the general racist views. It could be already observed in the beginning of the pandemic, when all Asian people were suspected of being carriers of the virus. The media provided numerous examples of acts of violence against Asians ${ }^{14}$.

\section{SHOCK AND RESILIENCE}

Today, in the end of March 2020 we know already that the coronavirus pandemic will have deep, global and long-lasting consequences. It is impossible to preview how profound will be the impact without knowing when the pandemic will end, but some forecasts, especially economical, are dreadful. This article is definitely not a place to examine economical prognosis, but few numbers should be given to highlight the scale of the threat. On $26^{\text {th }}$ March 2020 the Washington Post informed that during only one week nearly 3.3 million Americans filed for unemployment - a situation that has never happened in history. ${ }^{15}$ The newspaper cite forecasts which tell about up to 40 million lost jobs by the end of April. This would rise the US unemployment rate to nearly 25\%, which only happened in the peak of Great Depression of the 30-ies. In some sectors this drop will be possibly higher - as in tourism, transport, gastronomy, culture.

With the development of the pandemic, media informed about panic buying, empty shelves, even acts of aggression. But the shock will probably be causing other reactions, as results of social distancing, long time closing in small spaces, uncertainty, stress. Psychological, social and economic possible consequences of the crisis are hard to count. Maybe further problems will arise when people understand that the situa-

\footnotetext{
${ }^{14}$ https://www.latimes.com/california/story/2020-02-03/fear-panic-around-the-coronavirus-fuels-racist-sentiment. Donald Trump in some of his speeches referred to the coronavirus as "Chinese virus". Some regarded this expression as anti-Chinese.

15 https://www.washingtonpost.com/business/2020/03/26/unemployment-claims-coronavirus-3-mil$\underline{\text { lion/ }}$
} 
tion will remain such even longer.

Yet again it is interesting to watch how Europe reacted during and after the pandemic of the $14^{\text {th }}$ century. In the beginning there was chaos, non-understanding what happened, expectation that this would be the end of the world. People were seeking divine help or fell into hedonism as it is well described in the Prologue to Decameron. Many fields were abandoned, many beasts and herds were left unattended. But soon after people started to cope with the disaster, seeking rational explanations and methods of protection. Pandemic, although dreadful and resulting in massive casualties, in the long time perspective occurred to have also positive consequences, definitely pushing forward social and cultural change. Quattrocento followed by the birth of Renaissance in Italy reveals one of the greatest examples of resilience in the history of humanity (Kumpfer 1999).

\section{CONCLUSION}

Black Death (1347-1350) indeed was one of these events in the history of the world that reversed the way of thinking and in long term changed the society, economy, culture and politics. Together with several other issues, the pandemic opened a chain of transformations which put an end to the Middle Ages and marked the beginning of a new era, that in consequence led to early modernism.

In 2020 small invisible virus changed the world once again faster and more deeply than any politician or political event could do. Nobody can predict full consequences of the pandemic, but it may be, that some books will have to be rewritten - including those of Francis Fukuyama or Yuval Noah Harari. In 1991 when the Soviet Union collapsed, Fukuyama proclaimed the end of history and the appearance of the last man (Fukuyama 1992). Liberal democracy was to be the ultimate and global political system and although historical events still continue to happen, no one would question this truth. We still don't know how the virus would change the world, but it is already discussed if the liberal democracy was the most effective to confront the disease. Harari in turn presented in his book Homo Deus: A brief history of tomorrow (2016) a very optimistic view of the future of humanity - he wrote that for the first time in the history of mankind more people die of surfeit than hunger, more die of suicide than of war, finally more die of ageing than of contagious diseases. And even if an epidemic happens, we are able to react properly and cope with it. We don't blame God nor accept what happens as a must, but we find solutions. Well, the current pandemic seems to challenge these beliefs.

Every few years we are alarmed by the outbreak of some potential new plague, such as SARS in 2002/3, bird flu in 2005, swine flu in 2009/10 and Ebola in 2014. Yet thanks to efficient counter- measures these incidents have so far resulted in a comparatively small number of victims. SARS, for example, initially raised fears of a new Black Death, but eventually ended with the death of less than 1,000 peo- 
ple worldwide ${ }^{16}$. The Ebola outbreak in West Africa seemed at first to spiral out of control, and on 26 September 2014 the WHO described it as 'the most severe public health emergency seen in modern times'. Nevertheless, by early 2015 the epidemic had been reined in, and in January 2016 the WHO declared it over.

(Harari 2016: 32)

COVID-19 pandemic seems to be proving, that unlike it was told by Harari only a few years ago, humanity is not much better prepared to cope with such a threat, than it was in the $14^{\text {th }}$ century. Of course, time will show how quickly mankind would defeat the pandemic and at what cost. However, after only few weeks, it is clear and such is the majority of comments, that this situation has a potential to change much in the world's culture and social life. And maybe it could even be first step on the way towards the end of postmodernity and liberal democracy (assuming that there is an end and a beginning). Individualism may give a way to collectivity, authoritarian power may occur to be more effective and more attractive for hard times than democratic systems, tight borders may be needed again and institutions like the European Union will be perceived as ineffective.

In 2020 the humanity rediscovered a word that has been almost forgotten: quarantine. It was invented in the years after the Black Death emerged when ships calling at the port of Venice had to wait for 40 (quaranta in Italian) days before disembarking (Tognotti 2013: 255). Today, alike in the $14^{\text {th }}$ century, there is no better way to bypass the plague than isolation and closing, staying in one place and pray.

What lesson then comes to us from the history of the medieval disaster? The liminal period of the plague means reversing known social, economic, political and cultural order. It will (and it already does!) stigmatize social psychic, turn people away or towards God and religiosity, affect inter-human relations. But it will come to an end. After the liminal times a new order will emerge and it will probably be quite different from what we knew. In the $14^{\text {th }}$ century it brought an explosion of human creativity, individualism and one of the most fruitful periods in the history of culture. It is hoped that in $21^{\text {st }}$ century a similar mechanism will work.

FUNDING: This research received no external funding.

CONFLICT OF INTEREST: The author declares no conflict of interest.

\section{REFERENCES}

Ariès, Phillipe. 1989. Człowiek i śmierć. Transated by E. Bąkowska. Warsaw: PIW. Assman, Jan. 2008. "Communicative and Cultural Memory." Pp. 109-118 in Cultural

${ }^{16}$ COVID-19, as on 27 March 2020, caused 26,945 deaths worldwide, but these numbers are getting higher with increasing speed (https://www.worldometers.info/coronavirus/). 
Memory Studies: an International and Interdisciplinary Handbook, edited by A. Erll and A. Nünning. Berlin: Walter de Gruyter.

Barras, Vincent and Gilbert Greub. 2014. "History of biological warfare and bioterrorism.” Clinical Microbiology and infection 20 (6):497-502.

Boccaccio, Giovanni. 1929. Decameron. Translated by J. Payne. New York: Walter J. Black.

Britnel, Richard. 1994. “The Black Death in English towns.” Urban History 21(2):195210.

Caferro, William. 2018. Petrarch's War. Florence and Black Death in Context. Cambridge: CUP.

Cesana, Deneb, Ole J. Benedictow and Raffaella Bianucci. 2017. “The origin and early spread of the Black Death in Italy: first evidence of plague victims from 14th-century Liguria (northern Italy).” Anthropological Science 125(1): 15-24. https://doi. org/10.1537/ase.161011

Cohen, Daniel. 1974. The Black Death. 1347-1351. New York: Franklin Watts.

Fukuyama, Francis. 1992. The end of History and the Last Man. New York: Free Press.

Głowiński, Tomasz and Elżbieta Kościk. 2013. Od powietrza, głodu, ognia i wojny...: Klęski elementarne na przestrzeni wieków. Wrocław: Gajt.

Gottfried, Robert S. 1983. The Black Death. Natural and Human Disaster in Medieval Europe. New York-London-Toronto-Sydney: Free Press.

Harari, Yuval N. 2016. Homo Deus: A brief history of tomorrow. London: Harvill Secker. Huizinga, Johan. 1974. Jesień Średniowiecza. Translated by T. Brzostowski. Warsaw: PIW.

Kaufmann, Vincent, Manfred M. Bergman and Dominique Joye. 2004. "Motility: Mobility as Capital.” International Journal of Urban and Regional Research 28 (4): 745-756.

Kumpfer, Karol L. 1999. "Factors and Processes Contributing to Resilience: The Resilience Framework.” Pp. 179-224 in Resilience and Development: Positive Life Adaptations, edited by M. D. Glantz and J. L. Johnson. New York: Kluwer.

Kelly, John N.D. 1997. Encyklopedia Papieży. Translated by T. Szafrański. Warsaw: PIW. Mika, Bogumiła. 2008. „Suplikacje 'Święty Boże’ i ich muzyczny rezonans.” Muzyka Religijna - Między Epokami i Kulturami 1:149-172.

Naphy, William and Andrew Spicer. 2004. Czarna Śmierć. Translated by A. Dębska. Warsaw: PIW.

Patterson, David K. and Gerald F. Pyle. 1991. "The Geography and Mortality of the 1918 Influenza Pandemic.” Bulletin of the History of Medicine 65(1): 4-21.

Putnam, Bertha H. 1915. "Maximum Wage-Laws for Priests after the Black Death, 1348-1381." American Historical Review 21(1): 12-32.

Shipman, Pat. 2014. “The Bright Side of Black Death.” American Scientist 102: 410-413. Slavin, Phillip. 2019. "Death by the Lake: Mortality Crisis in Early Fourteen Century Central Asia." Journal of Interdisciplinary History 50(1): 59-90.

Thevenet, André. 1993. “Guy de Chauliac (1300-1370): the 'father of surgery’.” Annals of Vascular Surgery 7(2):208-212.

Tognotti, Eugenia. 2013. “Lessons from the History of Quarantine, from Plague to In- 
flenza A." Emerging Infectious Diseases 19 (2): 254-259.

The Holy Bible, New International Version. 1973. London: Hodder.

Tukidydes z Aten. 1988. Wojna peloponeska. Translated by K. Kumaniecki. Warsaw: Czytelnik.

Turner, Victor. 1967. Betwixt and Between: The Liminal Period in Rites de Passage. In the Forest of Symbols: aspects of Ndemburitual. London: Cornell University Press.

Twenge, Jean. 2019. iGen. Dlaczego dzieciaki dorastające w sieci sq mniej zbuntowane, bardziej tolerancyjne, mniej szczęśliwe - i zupetnie nieprzygotowane do dorosłości. Translated by Olga Dziedzic. Sopot: Smak Słowa.

van Gennep, Arnold. 2004. Rites of Passage. London: Routledge.

Zhou, Peng et al. 2020. "A pneumonia outbreak associated with a new coronavirus of probable bat origin.” Nature 579 (7798): 270-273.

Žižek, Slavoj. 2020. Pandemic! COVID-19 shakes the world. New York: OR Books.

\section{INTERNET SOURCES}

World Travel\&Tourism Council. 2019. Report. https://www.wttc.org/-/media/files/reports/economic-impact-research/regions-2019/world2019.pdf

https://www.lefigaro.fr/vox/monde/coronavirus-francais-ouvrez-les-yeux-sur-ledrame-que-vit-l-italie-livree-a-elle-meme-20200315

https://www.euractiv.pl/section/polityka-zagraniczna-ue/news/koronawirus-rosja-wyslala-do-wloch-pomoc-medyczna/

http://www.asianews.it/news-en/The-hypothesis-of-coronavirus-originating-from-a-laboratory-in-Wuhan-is-plausible-49550.html

https://edition.cnn.com/2020/03/22/world/doomsday-prophets-coronavirus-blake/ index.html

https://www.worldometers.info/coronavirus/

https://www.fox29.com/news/police-break-up-corona-party-at-apartment-in-trenton

https://www.businessinsider.com/whats-the-best-time-in-history-to-be-born-20149? $\mathrm{IR}=\mathrm{T}$

https://www.latimes.com/california/story/2020-02-03/fear-panic-around-the-coronavirus-fuels-racist-sentiment

https://www.washingtonpost.com/business/2020/03/26/unemployment-claims-coronavirus-3-million/

\section{BIOGRAPHICAL NOTE}

Wojciech Bedyński - ethnologist and historian of culture, graduate of the Paris IV (Sorbonne) University in Paris and the University of Warsaw. Currently employed in the Centre of Migration Research at the University of Warsaw. He specializes in the history of early medieval monasticism, inter-ethnic relations in pre-war East Galicia and cultural landscapes. 
OPEN ACCESS: This article is distributed under the terms of the Creative Commons Attribution Non-commercial License (CC BY-NC 4.0) which permits any non-commercial use, and reproduction in any medium, provided the original author(s) and source are credited.

ARTICLE HISTORY: Received 2020-03-30 / Accepted 2020-04-11 